Jurnal Penelitian Hutan Tanaman Vol. 14 No. 2, Desember 2017, 115-126

ISSN: 1829-6327, E-ISSN: 2442-8930

Terakreditasi No: 677/AU3/P2MI-LIPI/07/2015

\title{
KERAGAMAN DAN ESTIMASI PARAMETER GENETIK BIBIT MAHONI DAUN LEBAR (Swietenia macropylla King.) DI INDONESIA
}

\author{
Variation and Estimation of Genetic Parameter of Swietenia macrophylla King. Seedling \\ in Indonesia
}

\author{
Mashudi $^{1}$, Mudji Susanto ${ }^{1}$ dan/and Darwo $^{2}$ \\ ${ }^{1}$ Balai Besar Penelitian dan Pengembangan Bioteknologi dan Pemuliaan Tanaman Hutan \\ J1. Palagan Tentara Pelajar Km. 15, Purwobinangun, Pakem, Sleman, Yigyakarta \\ ${ }^{2}$ Pusat Penelitian dan Pengembangan Hutan \\ Jl. Gunung Batu No. 5, Bogor 16118 Po. Box 331 \\ Email: masshudy@yahoo.com; darwop3h@gmail.com
}

Tanggal diterima: 23 Mei 2017; Tanggal direvisi: 18 Desember 2017; Tanggal disetujui: 24 Desember 2017

\begin{abstract}

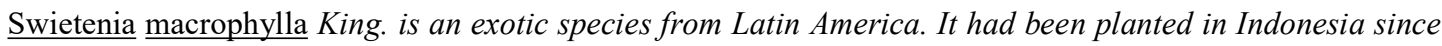
1870 by the Dutch. This species is important construction timber in Indonesia. This study aimed to measure variation and genetic parameter estimation of $\mathrm{S}$. macrophylla seedling as material of progeny trial development. The experimental design used Randomized Complete Block Design (RCBD) consisting of two factors, namely the land race (A) (Banjar-West Java, Samigaluh-Kulonprogro, Bondowoso-East Java and Lombok-West Nusa Tenggara) and mother trees (B) (35 mother trees). Five seedlings were recorded and repeated 5 times for each mother tree. In this study factor $B$ nested in factor $A$. The result showed that land race significantly affected to height, stem diameter, and index of robustness; while the mother trees significantly affected to height, stem diameter, number of leaf, and index of robustness. Individual heritability of height, stem diameter, number of leaf, and index of robustness character were 0.35, 0.40, 0.17, and 0.48 respectively, while family heritability of height, stem diameter, number of leaf, and index of robustness character were $0.74,0.75,0.54$, and 0.77 respectively. Genetic correlation between height and stem diameter (0.70), height and index of robustness (0.40), number of leaf and index of robustness (0.52) were positive value. While genetic correlation between height and number of leaf (-0.03), stem diameter and number of leaf (-0.46) and stem diameter and index of robustness (-0.67) were negative value.
\end{abstract}

Keywords : Genetic correlation, heritability, land race, Swietenia macrophylla, variation genetic

\begin{abstract}
ABSTRAK
Mahoni daun lebar (Swietenia macrophylla King.) merupakan jenis eksotik dari Amerika Latin yang telah ditanam di Indonesia sejak tahun 1870 oleh Belanda. Jenis ini merupakan kayu pertukangan yang penting di Indonesia. Tujuan penelitian adalah mengetahui keragaman dan nilai parameter genetik bibit $S$. macrophylla sebagai materi untuk membangun uji keturunan. Rancangan percobaan yang digunakan Rancangan Acak Lengkap Berblok Pola Tersarang yang terdiri dari dua faktor, yaitu ras lahan (Banjar-Jabar, SamigaluhKulonprogo, Bondowoso-Jatim, dan Lombok-NTB); dan pohon induk (35 pohon induk). Masing-masing pohon induk diamati 5 bibit dan diulang sebanyak 5 kali. Pada penelitian ini faktor pohon induk bersarang dalam faktor ras lahan. Hasil analisis menunjukkan bahwa ras lahan berpengaruh nyata terhadap pertumbuhan tinggi, diameter batang, dan indeks kekokohan, sedang pohon induk berpengaruh nyata terhadap pertumbuhan tinggi, diameter batang, jumlah daun, dan indeks kekokohan. Nilai heritabilitas individu sifat tinggi, diameter batang, jumlah daun, dan indeks kekokohan berturut-turut sebesar 0,35, 0,40, 0,17 , dan 0,48 , serta nilai heritabilitas famili untuk sifat tinggi, diameter batang, jumlah daun dan indeks kekokohan berturut-turut sebesar $0,74,0,75,0,54$, dan 0,77 . Korelasi genetik antara tinggi dengan diameter batang $(0,70)$, tinggi dengan indeks kekokohan $(0,40)$, dan jumlah daun dengan indeks kekokohan $(0,52)$ bernilai positif. Sementara itu korelasi genetik antara tinggi dengan jumlah daun $(-0,03)$, diameter batang dengan jumlah daun $(-0,46)$, dan diameter batang dengan indeks kekokohan $(-0,67)$ bernilai negatif.
\end{abstract}

Kata kunci : Heritabilitas, keragaman genetik, korelasi genetik, ras lahan, Swietenia macrophylla 


\section{PENDAHULUAN}

Kebutuhan bahan baku kayu untuk industri perkayuan di Indonesia cenderung meningkat dari tahun ke tahun, sementara itu produksi kayu dari hutan alam di luar Jawa terjadi sebaliknya. Berkaitan dengan semakin menurunnya kemampuan pro-duksi hutan alam secara lestari untuk menyediakan bahan baku industri, pembangunan hutan tanaman dengan produktivitas tinggi merupakan suatu ke-niscayaan. Salah satu jenis yang potensial untuk pengembangan hutan tanaman adalah mahoni daun lebar (Swietenia macrophylla King.).

S. macrophylla merupakan jenis eksotik dari famili Meliaceae yang secara alami tersebar di Amerika Latin. Tanaman $S$. macrophylla mulai dibudidayakan di Indonesia khususnya di Jawa sejak tahun 1870-an oleh Belanda (Krisnawati, Kallio, \& Kanninen, 2011). Awalnya jenis ini ditanam di pinggir jalan sebagai tanaman peneduh di sepanjang jalan Daendels (Merak sampai Banyuwangi). Saat ini tanaman $S$. macrophylla banyak dibudidayakan karena kayunya mempunyai nilai ekonomi yang tinggi dan merupakan pemasok kayu pertukangan yang cukup penting di Indonesia. Kayu $S$. macrophylla dapat digunakan sebagai bahan konstruksi, kayu lapis (plywood/ veneer), mebel (furniture), panel, frame, lantai (flooring), bodi mobil, interior perahu, moulding, dan lain-lain.

S. macrophylla termasuk tipe tanaman yang mampu hidup pada berbagai jenis tanah yang bebas genangan, reaksi tanah sedikit asam sampai basa, tanah gersang, atau marginal. Jenis ini juga mampu bertahan hidup walaupun tidak hujan selama berbulan-bulan. Pertumbuhan tanaman ini akan optimal apabila ditanam pada tanah subur, bersolum dalam dengan aerasi baik dan $\mathrm{pH}$ 6,5-7,5 serta elevasi sampai ketinggian $1.000 \mathrm{~m}$ dari permukaan laut (Mindawati \& Megawati, 2013). Krisnawati et al. (2011) menyampaikan bahwa rata-rata riap tahunan (Mean Annual Increment-MAI) volume tegakan S. macrophylla umur 15-30 tahun pada tapak dengan kesuburan sedang berkisar antara 7,7-19,3 $\mathrm{m}^{3} /$ ha/tahun. Mengacu pada hasil tersebut maka produktivitas hutan tanaman $S$. macrophylla perlu ditingkatkan. Untuk meningkatkan produktivitas hutan tanaman $S$. macrophylla kegiatan pemuliaan perlu dilakukan. Tuntutan ini didukung oleh hasil penelitian Siregar, Siregar, \& Novita (2007) yang menginformasikan bahwa ke-ragaman genetik $S$. macrophylla dari Jawa Tengah dan Jawa Timur dengan penanda isozim cukup tinggi sehingga seleksi me-mungkinkan untuk dilaksanakan. Dalam kegiatan pemuliaan, keragaman genetik memegang peran yang sangat penting sebab dengan nilai keragaman genetik yang tinggi maka seleksi yang dilakukan akan dapat menghasilkan perolehan genetik yang tinggi pula. Terkait dengan hal tersebut maka penelitian ini dilakukan dengan tujuan mengetahui keragaman dan nilai parameter genetik bibit $S$. macrophylla sebagai materi untuk membangun uji keturunan yang nantinya akan dikonversi menjadi kebun benih semai.

\section{METODOLOGI}

\section{A. Lokasi dan Waktu Penelitian}

Penelitian dilaksanakan di persemaian Balai Besar Penelitian Bioteknologi dan Pemuliaan Tanaman Hutan, Yogyakarta. Secara geografis lokasi penelitian berada pada 7040'35', LS dan $110^{\circ} 23^{\prime} 23^{\prime \prime}$ 'BT, ketinggian tempat $287 \mathrm{~m}$ di atas permukaan laut, curah hujan rata-rata $1.878 \mathrm{~mm} /$ tahun, suhu rata-rata $27^{\circ} \mathrm{C}$ dan kelembaban relatif $73 \%$. Penelitian dilaksanakan pada bulan Februari sampai Oktober 2016. Letak geografis dan ketinggian tempat 4 ras lahan S. macrophylla yang digunakan dalam penelitian ini disajikan pada Tabel 1 . 
Tabel (Table) 1. Letak geografis dan ketinggian tempat dari empat ras lahan $S$. macrophylla (Geographic position and altitude for four land races sources of $\underline{\mathrm{S}}$. macrophylla)

\begin{tabular}{|c|c|c|c|c|}
\hline No. & $\begin{array}{l}\text { Ras lahan } \\
\text { (Land race) }\end{array}$ & $\begin{array}{c}\text { Propinsi } \\
\text { (Province) }\end{array}$ & $\begin{array}{c}\text { Letak geografis } \\
\text { (Geographic position) }\end{array}$ & $\begin{array}{c}\text { Ketinggian tempat } \\
\text { (Altitude) } \\
\text { (m dpl) }\end{array}$ \\
\hline 1 & $\begin{array}{l}\text { Banjar, } \\
\text { Ciamis }\end{array}$ & Jawa Barat & $\begin{array}{c}007^{\circ} 21,144^{\prime}-007^{\circ} 30,026^{\prime} \mathrm{LS} \text { dan } \\
108^{\circ} 29,393^{\prime}-108^{\circ} 39,667^{\prime} \mathrm{BT}\end{array}$ & $75-250$ \\
\hline 2 & $\begin{array}{l}\text { Samigaluh, } \\
\text { Kulonprogo }\end{array}$ & $\begin{array}{l}\text { Daerah Istimewa } \\
\text { Yogyakarta }\end{array}$ & $\begin{array}{c}007^{\circ} 40,217^{\prime}-007^{\circ} 41,155^{\prime} \text { LS dan } \\
110^{\circ} 07,417^{\prime}-110^{\circ} 08,100^{\prime} \text { BT }\end{array}$ & $400-500$ \\
\hline 3 & Bondowoso & Jawa Timur & $\begin{array}{c}007^{\circ} 50,315^{\prime}-007^{\circ} 59,448 \text { LS dan } \\
113^{\circ} 48,217^{\prime}-113^{\circ} 59,671^{\prime} \mathrm{BT}\end{array}$ & $700-800$ \\
\hline 4 & Lombok & Nusa Tenggara Barat & $\begin{array}{c}008^{\circ} 31,913^{\prime}-008^{\circ} 40,835^{\prime} \text { LS dan } \\
116^{\circ} 14,311^{\prime}-116^{\circ} 23,718^{\prime} \text { BT }\end{array}$ & $250-500$ \\
\hline
\end{tabular}

\section{B. Prosedur Kerja \\ 1. Penyiapan bibit}

Untuk mendapatkan benih yang baik, buah diunduh dari pohon induk yang fenotipenya bagus. Buah yang telah diunduh selanjutnya diekstraksi dan kemudian dikecambahkan dalam bak tabur. Bak tabur yang digunakan berukuran 30x40x15 cm yang di dalamnya diisi pasir halus setebal 10-12 cm. Pengecambahan benih dilakukan dengan cara membenamkan benih pada media tabur sedalam $2 / 3$ bagian benih dengan posisi sayap di atas dengan jarak tanam $5 \times 3 \mathrm{~cm}$. Untuk menjaga kelembaban dilakukan penyiraman 1-2 kali sehari atau tergantung kondisi dan untuk mengurangi intensitas sinar matahari, di atas bedeng tabur dipasang naungan (paranet) dengan kerapatan $\pm 60 \%$. Benih $S$. macrophylla berkecambah pada 10-21 hari setelah penaburan dan pada hari ke-30 dilakukan penyapihan.

Penyapihan dilakukan pada polibag ukuran 10x15 $\mathrm{cm}$ dengan menggunakan media sapih top soil+kompos dengan perbandingan $4: 1$. Penyapihan dilakukan pada pagi hari, dengan tujuan untuk mengurangi kerusakan kecambah karena pengaruh suhu udara. Untuk mengurangi intensitas sinar matahari, di atas bedeng sapih dipasang naungan (paranet) dengan kerapatan $\pm 60 \%$. Agar pertumbuhan bibit setelah disapih optimal kegiatan pemeliharaan perlu dilakukan. Kegiatan pemeliharaan yang dilakukan meliputi penyiraman, penyiangan dan pengendalian hama/penyakit. Sampai umur 1 bulan kegiatan penyiraman dilakukan dua kali/ hari, yaitu pada pagi dan sore dan selepas umur 1 bulan penyiraman dilakukan satu kali/hari yaitu pada pagi hari. Kegiatan penyiangan dilakukan secara rutin (sebulan sekali). Pengendalian hama dan penyakit dilakukan apabila ada tandatanda serangan hama dan atau penyakit dengan menggunakan insektisida untuk serangan hama dan fungisida untuk serangan penyakit.

\section{Pengambilan data}

Pengambilan data dilakukan pada saat bibit berumur 5 bulan setelah penyapihan. Karakter yang diamati meliputi: tinggi bibit, diameter batang (2 $\mathrm{cm}$ dari permukaan media), jumlah daun, dan indeks kekokohan.

\section{Rancangan Penelitian}

Penelitian dilaksanakan dengan menggunakan Rancangan Acak Lengkap Berblok (RALB) Pola Tersarang yang terdiri dari dua faktor, yaitu ras lahan (A) dan pohon induk (B). Faktor A terdiri dari 4 ras lahan, yaitu Banjar- Jawa Barat, Samigaluh - Kulonprogo - DIY, 
Bondowoso - Jawa Timur dan Lombok Nusa Tenggara Barat. Faktor B terdiri dari 35 pohon induk (ras lahan Banjar 10 pohon induk, Samigaluh 10 pohon induk, Bondowoso 5 pohon induk dan Lombok 10 pohon induk). Dalam penelitian ini faktor B bersarang dalam faktor A. Masing-masing pohon induk diamati 5 bibit dan diulang sebanyak 5 kali.

\section{Analisis Data}

\section{Analisis varians}

Data hasil pengamatan dan pengukuran dianalisis menurut prosedur Rancangan Acak Lengkap Berblok Pola Tersarang. Untuk mengetahui perlakuan yang berpengaruh nyata dilakukan sidik ragam (analisis varians) dengan model sebagai berikut (Sastrosupadi, 2013):

$\mathrm{Y}_{i j k l}=\mu+\mathrm{R}_{i}+\mathrm{A}_{j}+\mathrm{B}_{k}\left(\mathrm{~A}_{j}\right)+\mathrm{R}^{*} \mathrm{~B}_{k}\left(\mathrm{~A}_{j}\right)+\varepsilon_{i j k l}$

Dimana :

$\mathrm{Y}_{i j k l}=$ Rata-rata pengamatan individu ke-l pada ulangan ke-i, ras lahan ke-j, pohon induk

ke-k; $\mu=$ Rata-rata umum; $\mathrm{R}_{i}=$ pengaruh ulangan ke-i; $\mathrm{A}_{j}=$ pengaruh ras lahan ke-j;

$\mathrm{B}_{k}\left(\mathrm{~A}_{j}\right)=$ Pengaruh pohon induk ke-k tersarang dalam ras lahan ke-j dan $\varepsilon_{i j k l}=$ galat.

\section{Heritabilitas}

Heritabilitas individu dan famili ditaksir menggunakan persamaan berikut (Hardiyanto, 2010) :

$$
\begin{aligned}
& h^{2}{ }_{i}=\frac{3 \sigma_{\mathrm{f}}^{2}}{\sigma_{\mathrm{f}}^{2}+\sigma_{\mathrm{fb}}^{2}+\sigma_{\mathrm{e}}^{2}} \\
& h^{2}=\frac{\sigma_{\mathrm{f}}^{2}}{\sigma_{\mathrm{f}}^{2}+\sigma_{\mathrm{fb} / \mathrm{B}}^{2}+\sigma_{\mathrm{e} / \mathrm{NB}}^{2}}
\end{aligned}
$$

Keterangan :

$h^{2}{ }_{i} \quad=$ Nilai heritabilitas individu

$h_{f}^{2} \quad=$ Nilai heritabilitas famili

$\sigma_{\mathrm{f}}^{2} \quad=$ Komponen varian famili

$$
\begin{aligned}
\sigma_{\mathrm{fb}}^{2}= & \text { Komponen varian interaksi } \\
& \text { famili dan blok } \\
\mathrm{B} & =\text { Rerata harmonik jumlah blok } \\
\mathrm{N}= & \text { Rerata harmonik jumlah } \\
& \text { individu per plot (ulangan) } \\
\sigma_{\mathrm{e}}^{2} & =\text { Komponen varian error }
\end{aligned}
$$

Pada persamaan heritabilitas individu, komponen varian famili $\left(\sigma_{\mathrm{f}}^{2}\right)$ diasumsikan sebesar $1 / 3$ varian genetik

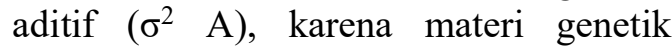
(benih) dikumpulkan dari pohon induk di hutan tanaman dengan penyebukan alami.

\section{Korelasi genetik}

Taksiran korelasi genetik antar sifat dihitung menggunakan formula berikut (Hardiyanto, 2010):

$$
r_{g}=\frac{\sigma_{f(x y)}}{\left(\sigma_{\left.f(x) \cdot \sigma^{2} f(y)\right)^{1 / 2}}\right.}
$$

Keterangan :

$$
\begin{aligned}
r_{g}= & \text { Korelasi genetik } \\
\sigma_{f(x y)}= & \text { Komponen kovarian famili } \\
& \text { untuk sifat } \mathrm{x} \text { dan } \mathrm{y} \\
\sigma_{f(x)}^{2}= & \text { Komponen varian famili untuk } \\
& \text { sifat } \mathrm{x} \\
\sigma^{2} f(y)= & \begin{array}{l}
\text { Komponen varian famili untuk } \\
\text { sifat } \mathrm{y}
\end{array}
\end{aligned}
$$

\section{HASIL DAN PEMBAHASAN}

\section{A. Hasil}

Berdasarkan hasil pengamatan dan pengukuran diketahui bahwa tinggi bibit, diameter batang, jumlah daun, dan indeks kekokohan bibit $S$. macrophylla umur 5 bulan cukup bervariasi. Hasil perhitungan menunjukkan bahwa rata-rata tinggi bibit antar pohon induk berkisar antara 27,57$45,52 \mathrm{~cm}$ (rata-rata $36,8 \pm 8,35 \mathrm{~cm}$ ), diameter batang berkisar antara $0,31-0,51$

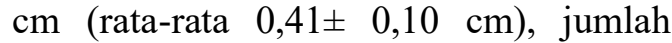
daun berkisar antara 8,44-11,88 helai (rata-rata 10,46 $\pm 2,21$ helai) dan indeks kekokohan berkisar antara 7,65-12,19 (rata-rata 9,13 $\pm 1,71$ ). Hasil analisis 
varians menunjukkan bahwa ras lahan ber-pengaruh sangat nyata terhadap pertumbuhan tinggi, diameter batang, dan indeks kekokohan bibit S. macrophylla umur 5 bulan. Kemudian pohon induk berpengaruh sangat nyata terhadap pertumbuhan tinggi, diameter batang, jumlah daun dan indeks kekokohan bibit S. macrophylla umur 5 bulan.

Perhitungan estimasi nilai komponen varians untuk masing-masing sifat yang diamati terhadap varians total disajikan pada Tabel 2 .

Heritabilitas merupakan parameter genetik yang sangat penting dalam kegiatan pemuliaan tanaman, sebab nilainya dapat digunakan untuk mengetahui seberapa besar proporsi faktor genetik dari induk diwariskan kepada keturunannya (Mangoendidjojo, 2009). Estimasi nilai heritabilitas untuk sifat tinggi, diameter batang, jumlah daun dan indeks ke-kokohan bibit $S$. macrophylla umur 5 bulan disajikan pada Tabel 3.

Untuk mengetahui keeratan hubungan antar sifat dilakukan perhitungan nilai korelasi genetik sebagaimana disajikan pada Tabel 4.

Tabel (Table) 2. Estimasi komponen varians dan proporsi masing-masing komponen varians terhadap total variasi pada bibit $S$. macrophylla umur 5 bulan (Component variance estimation and proportion of each variance component to total variation in 5 month age of $\underline{\text { S. macrophylla seedling) }}$

\begin{tabular}{|c|c|c|c|c|c|c|c|c|}
\hline \multirow{2}{*}{$\begin{array}{l}\text { Sumber } \\
\text { Variasi } \\
\text { (Sources of } \\
\text { variation) }\end{array}$} & \multicolumn{2}{|c|}{$\begin{array}{l}\text { Tinggi } \\
\text { (Height) }\end{array}$} & \multicolumn{2}{|c|}{$\begin{array}{l}\text { Diameter batang } \\
\text { (Stem diameter) }\end{array}$} & \multicolumn{2}{|c|}{$\begin{array}{c}\text { Jumlah daun } \\
\text { (Number of leaf) }\end{array}$} & \multicolumn{2}{|c|}{$\begin{array}{c}\text { Indeks kekokohan } \\
\text { (Index of } \\
\text { robustness) }\end{array}$} \\
\hline & $\begin{array}{l}\text { Komp. } \\
\text { varians } \\
\text { (Variance } \\
\text { somponent) }\end{array}$ & $\begin{array}{l}\text { Persen } \\
(\%)\end{array}$ & $\begin{array}{c}\text { Komp. } \\
\text { varians } \\
\text { (Variance } \\
\text { component) }\end{array}$ & $\begin{array}{c}\text { Persen } \\
(\%)\end{array}$ & $\begin{array}{c}\text { Komp. } \\
\text { varians } \\
\text { (Variance } \\
\text { component) }\end{array}$ & $\begin{array}{c}\text { Persen } \\
(\%)\end{array}$ & $\begin{array}{c}\text { Komp. } \\
\text { varians } \\
\text { (Variance } \\
\text { component) }\end{array}$ & $\begin{array}{c}\text { Persen } \\
(\%)\end{array}$ \\
\hline Ulg. & 0,00000 & 0,00 & 0,000038 & 0,33 & 0,01919 & 0,36 & 0,003801 & 0,09 \\
\hline RL & 4,11989 & 5,13 & 0,001002 & 8,57 & 0,00000 & 0,00 & 0,48891 & 11,84 \\
\hline PI (RL) & 6,19301 & 7,70 & 0,000660 & 5,65 & 0,29248 & 5,56 & 0,68346 & 16,55 \\
\hline Ulg. *PI (RL) & 2,99962 & 3,73 & 0,000598 & 5,11 & 0,33224 & 6,31 & 0,14326 & 3,47 \\
\hline Galat & 67,06974 & 83,44 & 0,009394 & 80,34 & 4,62229 & 87,77 & 2,81097 & 68,05 \\
\hline Total & 80,38226 & 100,00 & 0,011692 & 100,00 & 5,2662 & 100,00 & 4,130401 & 100,00 \\
\hline
\end{tabular}

Keterangan (Remarks): Ulg. = Ulangan (Replication); RL = Ras lahan (Land Race); PI = Pohon induk (Mother tree).

Tabel (Table) 3. Estimasi nilai heritabilitas individu dan heritabilitas famili sifat tinggi, diameter batang, jumlah daun dan indeks kekokohan bibit $S$. macrophylla umur 5 bulan (Estimation of individual heritability and family heritability to height, stem diameter, number of leaf and index of robustness in 5 month age of $\underline{\mathrm{S}}$. macrophylla seedling)

\begin{tabular}{lcc}
\hline \multicolumn{1}{c}{$\begin{array}{c}\text { Parameter } \\
\text { (Parameter) }\end{array}$} & $\begin{array}{c}\text { Heritabilitas individu } \\
\text { (Individual heritability) }\left(h^{2}\right)\end{array}$ & $\begin{array}{c}\text { Heritabilitas famili } \\
(\text { Family heritability })\left(h^{2}\right)\end{array}$ \\
\hline Tinggi (Height) & 0,35 & 0,74 \\
Diameter batang (Stem diameter) & 0,40 & 0,75 \\
Jumlah daun (Number of leaf) & 0,17 & 0,54 \\
Indeks kekokohan & 0,48 & 0,77 \\
(Index of robustness) & & \\
\hline
\end{tabular}




\section{B. Pembahasan \\ 1. Keragaman genetik}

Ras lahan berpengaruh nyata terhadap tinggi, diameter batang, dan indeks kekokohan bibit S. macrophylla umur 5 bulan. Hal ini sejalan dengan hasil penelitian Mashudi (2016) yang menginformasikan bahwa pertumbuhan tinggi dan diameter batang bibit $S$. macrophylla umur 2 bulan berbeda nyata antar asal sumber benih. Data tersebut sesuai dengan hasil penelitian Siregar et al. (2007) yang menyampaikan bahwa keragaman genetik $S$. macrophylla dari Jawa Tengah dan Jawa Timur dengan penanda isozim cukup tinggi (he $=0,326$ ) dengan proporsi keragaman antar asal sumber benih sebesar 23\%. Fakta ini diperkuat oleh penelitian Degen, Ward, Lemes, Navaro, Cavers, \& Sebbenn (2013) yang meng-informasikan bahwa deferensiasi populasi $S$. macrophylla pada sebaran alamnya di Amerika Latin berjalan cukup kuat. Fenomena tersebut juga didukung oleh hasil penelitian Rohandi \& Widyani (2010) dan Escalante, Saravia, \& Bravo (2012) yang menginformasikan bahwa asal sumber benih berpengaruh nyata terhadap pertumbuhan tinggi bibit $S$. macrophylla. Beberapa hasil penelitian tersebut memberi informasi bahwa S. macrophylla sebagai jenis eksotik di Indonesia, keragaman genetiknya relatif cukup tinggi sehingga informasi tersebut sangat penting untuk menyusun strategi pemuliaan jenis ini di Indonesia.

Pohon induk berpengaruh sangat nyata terhadap pertumbuhan tinggi, diameter batang, jumlah daun, dan indeks kekokohan bibit $S$. macrophylla umur 5 bulan. Pengaruh yang nyata pohon induk terhadap pertumbuhan tinggi, diameter batang dan jumlah daun juga terjadi pada pertumbuhan bibit $S$. macrophylla umur 2 bulan (Mashudi, 2016). Hal tersebut memberikan informasi bahwa dari umur dua sampai lima bulan pertumbuhan tinggi, diameter batang, dan jumlah daun bibit S. macrophylla antar pohon induk tetap beragam. Fenomena tersebut sesuai dengan hasil penelitian Siregar et al. (2007) yang menginformasikan bahwa proporsi keragaman genetik di dalam populasi S. macrophylla dari Jawa Tengah dan Jawa Timur dengan penanda isozym sebesar $77 \%$. Proporsi tersebut men-cerminkan bahwa keragaman genetik dari individu-individu penyusun populasi cukup tinggi sehingga keragaman per-tumbuhan anakan antar pohon induk signifikan perbedaannya.

Tabel (Table) 4. Estimasi nilai korelasi genetik $\left(\mathrm{r}_{g}\right)$ antar sifat bibit S. macrophylla umur 5 bulan (Estimation of genetic correlation $\left(r_{g}\right)$ between characters in 5 month age of S. macrophylla seedling)

\begin{tabular}{lcccc}
\hline $\begin{array}{l}\text { Korelasi genetik } \\
\text { (Genetic correlation) }\left(\mathrm{r}_{\mathrm{g}}\right)\end{array}$ & $\begin{array}{c}\text { Tinggi } \\
\text { (Height) }\end{array}$ & $\begin{array}{c}\text { Diameter batang } \\
\text { (Stem diameter) }\end{array}$ & $\begin{array}{c}\text { Jumlah daun } \\
\text { (Number of leaf) }\end{array}$ & $\begin{array}{c}\text { Indeks kekokohan } \\
\text { (Index of robustness) }\end{array}$ \\
\hline $\begin{array}{l}\text { Tinggi } \\
\text { (Height) }\end{array}$ & 0,40 & $-0,03$ & 0,40 \\
$\begin{array}{l}\text { Diameter batang } \\
\text { (Stem diameter) }\end{array}$ & 0,40 & $-0,46$ & $-0,67$ \\
$\begin{array}{l}\text { Jumlah daun } \\
\text { (Number of leaf) }\end{array}$ & $-0,03$ & $-0,46$ & & 0,52 \\
$\begin{array}{l}\text { Indeks kekokohan } \\
\text { (Index of robustness) }\end{array}$ & 0,40 & $-0,67$ & 0,52 & \\
\hline
\end{tabular}


Keragaman genetik yang cukup tinggi disebabkan oleh cukup besarnya proporsi komponen varians untuk masing-masing sifat yang diamati terhadap varians total, sebagaimana diperlihatkan pada Tabel 1. Komponen varian ras lahan memberikan sumbangan sebesar 5,13\% terhadap tinggi tanaman; $8,57 \%$ terhadap diameter batang; dan $11,84 \%$ terhadap indeks kekokohan. Sementara itu kom-ponen varian pohon induk memberikan sumbangan sebesar $7,70 \%$ terhadap tinggi tanaman; 5,65\% terhadap diameter batang; 5,56 terhadap jumlah daun; dan 16,55 terhadap indeks kekokohan. Dari data tersebut dapat dikatakan bahwa faktor genetik untuk sifat tinggi dan diameter batang masingmasing menempati proporsi antara 5$10 \%$. Nilai tersebut lebih tinggi bila dibanding dengan penelitian Muslimin, Sofyan, Suherman, Harisman, Voviarti, \& Susanti (2017) pada uji keturunan $S$. macrophylla King. umur 1 tahun di Kemampo, Sumatera Selatan. Pada penelitian tersebut faktor genetik untuk sifat tinggi menempati proporsi sebesar $4,57 \%$ dan 3,69\% untuk sifat diameter batang. Hal ini terjadi ke-mungkinan karena materi genetik yang digunakan dalam penelitian ini sebaran-nya relatif lebih luas dibanding dengan materi genetik yang digunakan dalam penelitian Muslimin et al. (2017), sehingga keragaman genetik dalam penelitian ini lebih tinggi. Disamping itu materi genetik tersebut sebagian besar berasal dari tanaman di daerah Sumatera Selatan dan Lampung, dimana pada dua daerah tersebut pengembangan tanaman $S$. macrophylla relatif belum lama dan materi genetik yang digunakan untuk mem-bangun berasal dari tanaman di pulau Jawa.

Proporsi komponen varian galat atau varian individu di dalam ulangan (plot) pada penelitian ini memiliki nilai sangat tinggi, hal tersebut mengindikasikan bahwa keragaman bibit di dalam plot tinggi. Tingginya nilai keragaman bibit di dalam plot bisa disebabkan oleh keragaman genetik di antara individu bibit di dalam satu pohon induk dan atau faktor di luar kendali penelitian. Dalam penelitian ini keragaman genetik antar individu anakan di dalam satu pohon induk sangat mungkin terjadi karena materi genetik yang digunakan dalam penelitian ini dikoleksi dari hutan tanaman sehingga perkawinan silang (out crossing) sangat mungkin terjadi. Hasil penelitian Lemes, Grattapaglia, Proctor, \& Gribel (2007) menginformasikan bahwa out crossing rate pada jenis ini sebesar 93,25\%. Dalam perkawinan silang di alam, satu pohon induk sangat terbuka untuk dibuahi oleh serbuk sari dari banyak induk jantan, akibatnya benih yang dikoleksi dari satu pohon induk berpotensi memiliki ke-ragaman genetik yang tinggi. Nilai komponen varian galat yang cukup tinggi juga ditemukan pada jenis nyawai (Ficus variegata Blume.) umur 8 bulan di persemaian (Haryjanto \& Prastyono, 2014), tanaman Eucalyptus pellita umur 12 bulan dan Acacia mangium umur 4 sampai 36 bulan (Leksono, 2008) serta tanaman kayu putih (Melaleuca cajuputi) umur 23 bulan (Susanto, 2008).

\section{Heritabilitas dan korelasi genetik}

Estimasi nilai heritabilitas individu sifat tinggi, diameter batang, jumlah daun dan indeks kekokohan berturut-turut sebesar 0,$35 ; 0,40 ; 0,17$, dan 0,48, sementara itu nilai heritabilitas famili untuk sifat tinggi, diameter batang, jumlah daun dan indeks kekokohan berturut-turut sebesar 0,$74 ; 0,75 ; 0,54$, dan 0,77 (Tabel 3). Nilai tersebut menunjukkan bahwa heritabilitas sifat tinggi, diameter batang dan indeks kekokohan termasuk dalam kriteria tinggi sedangkan untuk jumlah daun termasuk dalam kriteria sedang (moderat). Menurut Cotteril \& Dean (1990) heritabilitas individu termasuk dalam kriteria rendah 
jika nilainya $<0,1$, sedang (moderat) jika nilainya berkisar antara $0,1-0,3$ dan tinggi jika nilainya $>0,3$. Nilai heritabilitas sedang sampai tinggi tersebut memberikan petunjuk bahwa potensi keragaman genetik $S$. macrophylla cukup tinggi. Fenomena tersebut didukung oleh hasil penelitian Siregar et al. (2007) serta proporsi nilai komponen varian ras lahan dan pohon induk terhadap total komponen variannya cukup besar (Tabel 2).

Tingginya nilai heritabilitas $S$. macrophylla kemungkinan karena perhitungan dilakukan masih pada tingkat bibit di persemaian sehingga kondisi lingkungannya relatif masih seragam. Tingginya nilai heritabilitas diduga juga terjadi karena proporsi keragaman genetik di dalam ras lahan cukup besar (77\%) (Siregar et al., 2007) dan materi genetik yang digunakan dalam penelitian ini diambil dari beberapa ras lahan yang jaraknya berjauhan (Tabel 1) sehingga nilai varian genetik dari individu-individu penyusunnya cukup tinggi (Mangoendidjojo, 2009). Nilai heritabilitas yang cukup tinggi pada tingkat bibit di persemaian juga terjadi pada jenis nyawai (Ficus variegata Blume) umur 8 bulan (Haryjanto \& Prastyono, 2014) dan meranti tembaga (Shorea leprosula Miq.) umur 18 bulan (Mashudi, 2017).

Penelitian tingkat lapang oleh Muslimin et al. (2017) pada plot uji keturunan $S$. macrophylla umur 1 tahun di Kemampo, Sumatera Selatan menunjuk-kan bahwa nilai heritabilitas individu sifat tinggi dan diameter batang masing-masing sebesar 0,22 dan 0,19 dan heritabilitas famili masing-masing sebesar 0,47 dan 0,42. Penelitian di Mexico pada kombinasi uji provenan dan uji keturunan $S$. macrophylla umur 5 tahun dihasilkan nilai heritabilitas individu untuk sifat tinggi sebesar 0,26 pada lahan yang kurang subur dan 0,31 pada lahan yang subur (Wightman, Ward, Haggar, Santiago, \& Cornelius, 2008). Pada dua penelitian tersebut nilai heritabilitasnya lebih kecil dibanding dengan nilai heritabilitas pada tingkat bibit di persemaian. Hal tersebut dapat dipahami karena di tingkat per-semaian kondisi lingkungan relatif se-ragam sehingga nilai heritabilitas yang diperoleh relatif lebih tinggi (Haryjanto \& Prastyono, 2014). Dibanding di persemaian, tanaman di tingkat lapang nilai heritabilitasnya cenderung akan berkurang karena proporsi faktor lingkungan cukup bersar pengaruhnya terhadap fenotipe. Pada tingkat lapang, nilai heritabilitas berpotensi untuk berubah sebab pe-ngendalian gen terhadap pertumbuhan tanaman dimungkinkan berubah seiring dengan bertambahnya umur (Missanjo, Thole, \& Manda, 2013). Disamping umur, perbedaan lokasi uji dan jenis tanaman menjadi penyebab nilai heritabilitas berubah, sebab nilai heritabilitas hanya berlaku untuk jenis tertentu dan pada lokasi tertentu (Mashudi \& Susanto, 2016). Beberapa jenis tanaman yang mengalami perubahan nilai heritabilitas karena bertambahnya umur diantaranya : jati (Tectona grandis) (Hadiyan, 2009), araukaria (Araucaria cunninghamii) (Setiadi, 2010; Setiadi \& Susanto, 2012), Eucalyptus pellita (Leksono, 2008), dan Acacia mangium (Nirsatmanto, Kurinobu, \& Shiraishi, 2012).

Korelasi genetik antar sifat dalam ilmu pemuliaan lazimnya digunakan untuk efisiensi pelaksanaan seleksi. Jika korelasi bernilai positif kuat dan konsisten sampai tanaman siap diseleksi maka pe-laksanaan seleksi bisa menggunakan dasar satu sifat saja. Korelasi genetik bernilai positif menunjukkan bahwa perbaikan satu sifat akan diikuti oleh perbaikan sifat yang lain dengan derajat hubungan se-besar nilai korelasinya, sebaliknya untuk korelasi negatif perbaikan satu sifat akan diikuti oleh penurunan sifat yang lain dengan derajat hubungan sebesar nilai korelasinya. 
Korelasi genetik antara tinggi dengan diameter batang nilainya positif cukup tinggi $(0,70)$, sedang korelasi genetik antara tinggi dengan indeks kekokohan $(0,40)$ dan jumlah daun dengan indeks kekokohan $(0,52)$ bernilai positif kurang tinggi (Tabel 4). Sementara itu korelasi genetik antara sifat tinggi dengan jumlah daun $(-0,03)$ dan diameter batang dengan jumlah daun $(-0,46)$ nilainya negatif kurang tinggi serta diameter batang dengan indeks kekokohan $(-0,67)$ nilainya negatif cukup tinggi.

Korelasi genetik antara sifat tinggi dengan diameter batang bernilai positif cukup tinggi, hal ini dapat dipahami karena pertambahan tinggi tanaman lazimnya akan diikuti oleh pertambahan diameter batang. Fenomena tersebut juga ditemui pada beberapa jenis tanaman kehutanan, diantaranya nyawai (Ficus variegata Blume) (Haryjanto \& Prastyono, 2014), pulai gading (Alstonia scholaris) (Husada, 2013), araukaria (Araucaria cunninghamii) (Setiadi, 2010), dan sengon (Falcataria moluccana) (Ismail \& Hadiyan, 2008). Yang perlu diperhatikan adalah korelasi genetik antara tinggi dengan indeks kekokohan yang bernilai positif karena dengan ber-tambahnya nilai indeks kekokohan maka bibit semakin kurus (Yudhohartono \& Fambayun, 2012). Bibit dengan nilai indeks kekokohan yang tinggi (kurus) akan rentan terhadap kerusakan pada saat penanganan, angin dan kekeringan (Haase, 2008). Indeks kekokohan bibit termasuk kategori baik apabila nilainya lebih kecil dari 6 (Jaenicke, 1999). Dalam penelitian ini, korelasi genetik antara diameter batang dengan indeks kekokohan $(-0,67)$ bernilai negatif cukup tinggi dan ini merupakan indikasi yang positif, sebab dengan bertambahnya diameter batang akan diikuti dengan menurunnya nilai indeks kekokohan (bibit semakin kokoh).

\section{IV.KESIMPULAN DAN SARAN}

\section{A. Kesimpulan}

Keragaman pertumbuhan tinggi, diameter batang dan indeks kekokohan dipengaruhi oleh ras lahan dan pohon induk. Keragaman pertumbuhan jumlah daun dipengaruhi oleh pohon induk. Estimasi nilai heritabilitas individu sifat tinggi, diameter batang dan indeks kekokohan termasuk dalam kriteria tinggi, yaitu masing-masing sebesar 0,35 , 0,40 dan 0,48 sedangkan untuk jumlah daun termasuk dalam kriteria sedang (moderat yaitu sebesar 0,17). Korelasi genetik antara tinggi dengan diameter batang nilainya positif cukup tinggi, sedang korelasi genetik antara tinggi dengan indeks kekokohan dan jumlah daun dengan indeks kekokohan bernilai positif kurang tinggi. Korelasi genetik antara sifat tinggi dengan jumlah daun dan diameter batang dengan jumlah daun bernilai negatif kurang tinggi serta diameter batang dengan indeks kekokohan bernilai negatif cukup tinggi.

\section{B. Saran}

Pengendalian gen terhadap pertumbuhan tanaman sangat dimungkinkan berubah seiring dengan bertambahnya umur dan perubahan lokasi uji. Terkait dengan hal tersebut penelitian lanjutan untuk mengetahui keragaman dan nilai parameter genetik $S$. macrophylla pada tingkat lapang perlu dilakukan secara berkala.

\section{UCAPAN TERIMA KASIH}

Penelitian ini dibiayai DIPA APBN Balai Besar Penelitian dan Pengembangan Bioteknologi dan Pemuliaan Tanaman Hutan. Ucapan terima kasih disampaikan kepada Maman Sulaeman dan Samsudin yang telah membantu penelitian dan pengumpulan data. Begitu juga kepada 
anggota tim peneliti pemuliaan kayu pertukangan dan semua pihak yang telah berkontribusi dalam penelitian.

\section{DAFTAR PUSTAKA}

Cotteril, P.P., \& Dean, C.A. (1990). Successful tree breeding with index selection. CSIRO Division of Forestry and Forest Product, Australia.

Degen, B., Ward, S.E., Lemes, M.R., Navarro, C., Cavers, S., \& Sebbenn, A.M. (2013). Verifying the geographic origin of mahogany (Swietenia macrophylla King) with DNA-fingerprint $S . \quad$ Forensic Science International: Genetics, 7(1), 55-62. https:// doi.org/10. 1016/j.fsigen.2012.06.003

Escalante, E., Saravia, P., \& Bravo, F. (2012). Survival and growth of bigleaf mahogany

(Swietenia macrophylla King ) seedlings in two provenance trials in Bolivia. Ecologia En Bolivia, 47(1), 37-52.

Haase, D.L. (2008). Understanding forest seedling quality: measurenents and interpretation. Tree Planters' Notes, 52(2), 24-30.

Hadiyan, Y. (2009). Keragaman pertumbuhan uji keturuna jati (Tectona grandis L.F.) umur 5 tahun di Ciamis, Jawa Barat. Jurnal Pemuliaan Tanaman Hutan, 3(2), 95-102.

Hardiyanto, E.B. (2010). Diktat mata kuliah pemuliaan pohon lanjut. Yogyakarta: Fakultas Kehutanan Universitas Gadjah Mada.

Haryjanto, L., \& Prastyono. (2014). Pendugaan parameter genetik semai nyawai (Ficus variegata Blume) asal Pulau Lombok. Jurnal Penelitian Kehutanan Wallacea, 3(1), 37-45.
Husada, A. (2013). Evaluasi uji keturunan pulai gading (Alstonia scholaris) pada umur 4 tahun di Petak 93, Playen, Gunung Kidul, Yogyakarta.

Ismail, B., \& Hadiyan, Y. (2008). Evaluasi awal uji keturunan sengon (Falcataria moluccana) umur 8 bulan di Kabupaten Kediri Jawa Timur. Jurnal Pemuliaan Tanaman Hutan, 2(3), 1-7.

Jaenicke, H. (1999). Practical guidelines for research nurserieS. In Good tree nursery practices (pp. 8-15). Nairobi, Kenya: ICRAF.

Krisnawati, H., Kallio, M., \& Kanninen, M. (2011). Swietenia macrophylla King. : Ecology, silviculture and productivity. Bogor, Indonesia: CIFOR.

Leksono, B. (2008). Study on breeding strategy of Eucalyptus pellita (Doctoral Thesis). The University of Tokyo.

Lemes, M.R., Grattapaglia, D., Proctor, J., \& Gribel, R. (2007). Flexible mating system in a logged population of Swietenia macrophylla King (Meliaceae): implications for the management of a threatened neotropical tree specieS. Plant Ecology, 192(2), 169-179.

Mangoendidjojo, W. (2009). Dasardasar pemuliaan tanaman. Yogyakarta: KanisiuS.

Mashudi. (2016). Keragaman pertumbuhan bibit mahoni daun lebar (Swietenia macrophylla King.) dari dua populasi di Yogyakarta. In A. Hayati, D. Winarni, H. Purnobasuki, Ni'matuzahroh, T. Soedarti, \& Kuncoro, E.P. (Eds.), Prosiding Nasional Biodiversitas $V I$ (pp. 121-129). Surabaya: Departemen Biologi Fakultas Sains dan Teknologi Universitas Airlangga. 
Mashudi. (2017). Keragaman dan estimasi parameter genetik meranti tembaga (Shorea leprosula Miq.) dari beberapa provenan di Kalimantan. In A. Asngad, Suparti, Hariyatmi, Djumadi, E. Setyaningsih, T. Rahayu, ... Y. Sidiq (Eds.), Prosiding Seminar Nasional Pendidikan Biologi dan Saintek (pp. 264-271). Surakarta: Program Studi Pendidikan Biologi FKIP UMS Surakarta.

Mashudi, \& Susanto, M. (2016). Evaluasi uji keturunan pulai darat (Alstonia angustiloba Miq.) umur tiga tahun di Wonogiri, Jawa Tengah. Jurnal Pemuliaan Tanaman Hutan, 10, 83-93.

Mindawati, N., \& Megawati. (2013). Manual budidaya mahoni (Swietenia macrophylla King.). Bogor, Indonesia: Puslitbang Peningkatan Produktivitas Hutan dan Direktorat Perbenihan Tanaman Hutan.

Missanjo, E., Thole, G.K., \& Manda, V. (2013). Estimation of genetic and phenotypic parameters for growth traits in clonal seed orchard of Pinus kesiya in Malawi. International Scholarly Research Network Forestry, (1-6).

Muslimin, I., Sofyan, A., Suherman, E., Harisman, Y., Voviarti, H., \& Susanti, D. (2017). Evaluasi awal uji keturunan mahoni (Swietenia macrophylla King.) umur 1 tahun di Kemampo, Banyuasin, Sumatera Selatan. In Lukman, A.H., Nurfatriani, F., Lelana, N.E., \& Djaenudin, R.D. (Eds.), Prosiding Ekspose Hasil Penelitian (pp. 3945). Palembang: Balai Penelitian dan Pengembangan Lingkungan Hidup dan Kehutanan Palembang.

Nirsatmanto, A., Kurinobu, S., \& Shiraishi, S. (2012). Evaluation for the efficiency of early selection in Acacia mangium seedling seed orchards based on age trends in genetic parameter. Indonesian Journal of Forestry Research, 9(1), $16-24$.

Rohandi, A., \& Widyani, N. (2010). Pertumbuhan tiga provenans mahoni asal Kostarika. Tekno Hutan Tanaman, 3(1), 7-11.

Sastrosupadi, A. (2013). Rancangan percobaan praktis bidang pertanian (Cetakan ke). Yogyakarta: Kanisius.

Setiadi, D. (2010). Keragaman genetik uji provenan dan uji keturunan Araucaria cunninghamii pada umur 18 bulan di Bondowoso, Jawa Timur. Jurnal Pemuliaan Tanaman Hutan, 4(1), 1-8.

Setiadi, D., \& Susanto, M. (2012). Variasi genetik pada kombinasi uji provenans dan uji keturunan Araucaria cunninghamii di Bondowoso, Jawa Timur. Jurnal Pemuliaan Tanaman Hutan, 6(3), 157-166.

Siregar, U.J., Siregar, I.Z., \& Novita, I. (2007). Keragaman fenotipik dan genetik mahoni (Swietenia macrophylla) di Jawa Tengah dan Jawa Timur. In Prosiding Seminar Nasional Hasil Penelitian Yang Dibiayai oleh Hibah Kompetitif (pp. 161-164). Bogor.

Susanto, M. (2008). Analisis Komponen Varian Uji Keturunan Melaleuca cajuputi subsp. cajuputi di Paliyan, Gunungkidul. Jurnal Penelitian Hutan Tanaman, 5(Suplemen No. 1), 199-207.

Wightman, K.E., Ward, S.E., Haggar, J.P., Santiago, B.R., \& Cornelius, J.P. (2008). Performance and genetic variation of big-leaf mahogany (Swietenia macrophylla 
Jurnal Penelitian Hutan Tanaman

Vol. 14 No. 2, Desember 2017, 115-125

King) in provenance and progeny trials in the Yucatan Peninsula of Mexico. Forest Ecology and Management, 255(2), 346-355.

Yudhohartono, T.P., \& Fambayun, R.A. (2012). Karakteristik pertumbuhan semai binuang asal provenan Pasaman, Sumatera Barat. Jurnal Pemuliaan Tanaman Hutan, 6(3), 143-156. 